\title{
Synthesis and physical-chemical properties of 3-benzyl- 8-propylxanthinyl-7-acetic acid and its derivatives
}

\author{
Zaporizhzhia State Medical University, Ukraine
}

\begin{abstract}
Introduction. Heterocyclic compounds play an important role in the metabolic processes of human organism. Structures of vitamins, nucleotides, chromoproteins are based on Nitrogen-containing heterocycles (purine, pyrimidine, thiazole etc). Thus, it was obvious to use these organic substances as basic molecules for synthetic research of biologically active compounds which could be used for treatment of different pathological processes. In their research, some scientist pay special attention to xanthine derivatives that are well-known low toxic natural compounds with wide spectrum of pronounced pharmacological properties (antioxidant, diuretic, antibacterial, anti-inflammatory etc). Insertion of carboxyl group in the structure of xanthine molecule is a prospective ability of its synthetic potential increasing.

Aim of our research was the development of method of 3-benzyl-8-propylxanthinyl-7-acetic acid and its derivatives synthesis and studying their physical-chemical properties.

Materials and methods. Melting points were determined using capillary method on DMP (M). ${ }^{1} \mathrm{H}$ NMR-spectra were recorded by Varian Mercury VX-200 device (company «Varian», USA) solvent - (DMSO-d6), internal standard - TMS. Elemental analysis of obtained compounds was produced on device Elementar Vario L cube.

Results and discussion. We selected 3-benzyl-8-propyl xanthine as initial compound for our study. By its interaction with chloroacetic acid, chloroacetamide or propyl chloroacetate in DMF in the presence of calculated amount of $\mathrm{NaHCO}_{3}$ we synthesized 3-benzyl-8propylxanthinyl-7-acetic acid its ester and amide. At the same time we found that obtaining of xanthinyl-7-acetic acid by hydrolysis of its ester produced with higher yield. On the next stage of our research we synthesized a number of water-soluble salts of 3-benzyl-8propylxanthinyl-7-acetic acid by reaction of acid with different primary and secondary amines. The structures of all obtained compounds were proved by the elemental analysis and ${ }^{1} \mathrm{H}$ NMR-spectroscopy.
\end{abstract}

Conclusions. Obtained results of our work can be used for further search of biologically active compounds among xanthine derivatives with carboxyl residue.

Key words: xanthines, organic synthesis, NMR-spectroscopy.

Current issues in pharmacy and medicine: science and practice 2017; 10 (1), 14-19

\section{Синтез і фізико-хімічні властивості 3-бензил-8-пропілксантиніл-7-ацетатної кислоти та її похідних}

С. К. Михальченко, К. В. Александрова, С. В. Левіч, Д. М. Сінченко

Гетероциклічні сполуки відіграють важливу роль у метаболічних процесах організму людини. В основі структур вітамінів, нуклеотидів, хромопротеїнів - нітрогеновмісні гетероцикли (пурин, піримідин, тіазол тощо). Виходячи з вищесказаного, очевидним $є$ використання цих речовин як базових молекул для синтетичних досліджень із пошуку біологічно активних речовин, що можуть застосовуватися для лікування різноманітних патологічних станів. Багато науковців у своїх дослідженнях особливу увагу приділяють похідним ксантину, що $є$ відомими природними сполуками з низькою токсичністю та широким спектром вираженої фармакологічної дії (антиоксидантної, діуретичної, протимікробної тощо). Введення до структури ксантинової молекули карбоксильної групи може значно підвищити іiї синтетичний потенціал.

Мета роботи - розробити препаративний метод синтезу похідних 3-бензил-8-пропілксантиніл-7-ацетатної кислоти та вивчити їхні фізико-хімічні властивості.

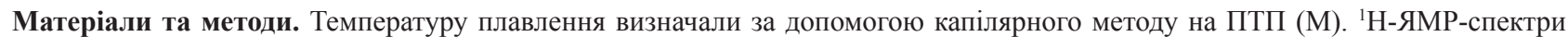
реєстрували за допомогою Varian Mercury VX-200 - розчинник (ДМСО-d6), внутрішній стандарт - ТМС. Елементний аналіз сполук, що одержали, здійснили на пристрої Elementar Vario L Cube.

Результати. Як вихідну сполуку для дослідження обрали 3-бензил-8-пропілксантин. Далі одержали 3-бензил-8-пропілксантиніл-7-ацетатну кислоту, їі естер та амід взаємодією 3-бензил-8-пропілксантину з хлорацетатною кислотою, пропілхлорацетатом і хлороацетамідом у ДМФА у присутності розрахованої кількості $\mathrm{NaHCO}_{3}$. Встановили, що ксантиніл-7-ацетатну кислоту 3 більшим виходом можна одержати гідролізом естеру. Наступною стадією нашої роботи було одержання ряду водорозчинних солей 3-бензил-8-пропілксантиніл-7-ацетатної кислоти взаємодією кислоти 3 різноманітними первинними та вторинними амінами. Структури всіх сполук, що одержали, доведені методами елементного аналізу та ${ }^{1} \mathrm{H}-Я$ МР-спектроскопії.

Висновки. Результати, що одержали, можуть бути використані для пошуку біологічно активних сполук серед карбоксилвмісних ксантинів.

Ключові слова: ксантини, органічний синтез, ЯМР-спектроскопія.

Актуальні питання фармацевтичної і медичної науки та практики. - 2017. - Т. 10, № 1(23). - С. 14-19

Синтез и физико-химические свойства 3-бензил-8-пропилксантинил-7-ацетатной кислоты и её производных

Е. К. Михальченко, Е. В. Александрова, С. В. Левич, Д. Н. Синченко

Гетероциклические соединения играют важную роль в метаболических процессах организма человека. В основе структур витаминов, нуклеотидов, хромопротеинов - азотосодержащие гетероциклы (пурин, пиримидин, тиазол и т. д.). Исходя из вышесказанного, очевидным становится использование данных веществ в качестве базовых молекул для синтетических ис- 
следований по поиску биологически активных веществ, которые могут применяться для лечения различных патологических состояний. Многие учёные в своих исследованиях особое внимание уделяют производным ксантина, которые, как известно, являются природными соединениями с низкою токсичностью и широким спектром выраженного фармакологического действия (антиоксидантного, диуретического, противомикробного и т. д.). Введение в структуру ксантиновой молекулы карбоксильной группы может значительно повысить её синтетический потенциал.

Цель работы - разработка препаративного метода синтеза производных 3-бензил-8-пропилксантинил-7-ацетатной кислоты и изучение её физико-химических свойств.

Материалы и методы. Температуру плавления определяли с помощью капиллярного метода на ПТП (М). ${ }^{1}$ Н-ЯМР-спектры регистрировали с помощью Varian Mercury VX-200 - растворитель (ДМСО-dб), внутренний стандарт - ТМС. Элементный анализ соединений был проведён на приборе Elementar Vario L Cube.

Результаты. В качестве исходного соединения для исследований нами были выбраны 3-бензил-8-пропилксантины. Далее были получены 3-бензил-8-пропилксантинил-7-ацетатная кислота, её эфир и амид взаимодействием 3-бензил-8-пропилксантина с хлорацетатной кислотой, пропилхлорацетатом и хлороацетамидом в ДМФА в присутствии рассчитанного количества аНСО . Установлено, что ксантинил-7-ацетатную кислоту с большим выходом можно получить гидролизом эфира. Следующей стадией нашей работы было получение ряда водорастворимых солей 3-бензил-8-пропилксантинил-7-ацетатной кислоты взаимодействием кислоты с различными первичными и вторичными аминами. Структуры всех полученных соединений были доказаны

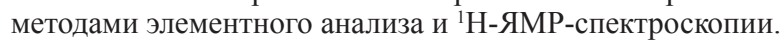

Выводы. Полученные в ходе нашей работы результаты могут быть использованы для дальнейшего поиска биологически активных соединений среди карбоксилсодержащих ксантинов.

Ключевые слова: ксантины, органический синтез, ЯМР-спектроскопия.

Актуальные вопросы фармацевтической и медицинской науки и практики. - 2017. - T. 10, № 1(23). - С. 14-19

$\mathrm{H}^{2}$ terocyclic compounds play an important role in the metabolic processes of human organism. Structures of vitamins, nucleotides, chromoproteins are based on Nitrogen-containing heterocycles (purine, pyrimidine, thiazole etc) $[1]$.

Thus, it was obvious to use these organic substances as basic molecules for synthetic research of biologically active compounds that could be used for treatment of different pathological processes [2,3]. In their research, some scientist paid special attention to xanthine derivatives that are wellknown low toxic natural compounds with wide spectrum of pronounced pharmacological properties (antioxidant, diuretic, antibacterial, anti-inflammatory etc). It should be noted, that xanthines have also high variability of chemical modification [4-8], that make them good objects for pharmaceutical research.

Carboxyl group is one of the most chemically active functional group. It easily interacts with reagents in reactions of nucleophilic substitution. At the same time this functional group shows acidic properties that could be used for obtaining water-soluble derivatives of insoluble acids. Thus, insertion of carboxyl group in the structure of xanthine molecule is a prospective ability of its synthetic potential increasing [9].

\section{Aim of the work}

The aim of work is the development of method of 3-benzyl-8-propylxanthinyl-7-acetic acid and its derivatives synthesis and studying their physical-chemical properties.

\section{Materials and methods}

Melting points were determined using capillary method on DMP (M). ${ }^{1} \mathrm{H}$ NMR-spectra were recorded by Varian Mercury VX-200 device (company «Varian», USA) solvent - (DMSO-d6), internal standard - TMS. Elemental analysis of obtained compounds was produced on device Elementar
Vario L cube.

3-Benzyl-8-propylxanthine (1) was synthesized by method that we had described earlier [10].

3-Benzyl-8-propylxanthinyl-7-acetic acid (2). Method A. To $2.84 \mathrm{~g}$ (0,01 mole) of 3-benzyl-8-propylxanthine $115 \mathrm{ml}$ DMF and $1.84 \mathrm{~g}$ (0.022 mole) $\mathrm{NaHCO}_{3}$ were added and mixture was heated for $15 \mathrm{~min}$. After this $1.04 \mathrm{~g}(0.011 \mathrm{~mole})$ of chloracetic acid was added and mixture was refluxed for $2 \mathrm{~h}$. Then solution was filtered. Filtrate was cooled, diluted with $50 \mathrm{ml}$ of water. Precipitate, which appeared after $0.1 \mathrm{M}$ sulfuric acid addition (up to $\mathrm{pH}$ 2), was filtered out, washed by water, dried at $80-85^{\circ} \mathrm{C}$ and finally crystallized from ethanol.

Method B. $3.84 \mathrm{~g}$ (0.01 mole) of ester 3 or $3.41 \mathrm{~g}(0.01$ mole) of amide 4 was dissolved in $90 \mathrm{ml}$ of $0.5 \mathrm{M}$ solution of $\mathrm{NaOH}$. Mixture was stirred and refluxed for $2 \mathrm{~h}$. Then solution was filtered. Filtrate was cooled, diluted with $50 \mathrm{ml}$ of water and neutralized by $0.1 \mathrm{M}$ sulfuric acid (up to $\mathrm{pH}$ 2). Precipitate was filtered out, washed by water, dried at $80-85^{\circ} \mathrm{C}$ and finally crystallized from ethanol.

Yield $92 \%$. M.p. $242-244{ }^{\circ}$ C. $\mathrm{C}_{17} \mathrm{H}_{18} \mathrm{~N}_{4} \mathrm{O}_{4}$. Found, \%: C, 59.78; H, 5.32; N, 16.43. Calculated, \%: C, 59.64; H, 5.30; N, 16.37. ${ }^{1} \mathrm{H}$ NMR-spectrum ( $\delta$-scale, ppm., solvent DMSO- $\left.d_{6}\right)$ : $12.61(1 \mathrm{H}, \mathrm{s} \mathrm{OH}), 11.12\left(1 \mathrm{H}, \mathrm{s}, \mathrm{N}^{1} \mathrm{H}\right), 7.32-7.11(5 \mathrm{H}, \mathrm{m}$, $\left.\mathrm{CH}_{\text {aром }}\right), 5.02\left(2 \mathrm{H}, \mathrm{s}, \mathrm{N}^{3}-\mathrm{CH}_{2}\right), 4.97\left(2 \mathrm{H}, \mathrm{s}, \mathrm{N}^{7}-\mathrm{CH}_{2}\right), 2.59$ $\left(2 \mathrm{H}, \mathrm{t}, \mathrm{C}^{8}-\mathrm{CH}_{2}\right), 1.62\left(2 \mathrm{H}, \mathrm{m}, \mathrm{C}^{8}-\mathrm{C}-\mathrm{CH}_{2}\right), 0.88\left(3 \mathrm{H}, \mathrm{t}, \mathrm{CH}_{3}\right)$. Propyl 3-benzyl-8-propylxanthinyl-7-acetare (3). Method A. To 2.84 г (0.01 mole) of 3-benzyl-8-propylxanthine 115 $\mathrm{ml}$ DMF and $0.92 \mathrm{~g}(0,011$ mole $) \mathrm{NaHCO}_{3}$ were added and mixture was heated for $15 \mathrm{~min}$. After this 0.011 mole of propyl chloroacetate was added and mixture was refluxed for $2 \mathrm{~h}$. Then solution was filtered. Filtrate was cooled, diluted with $50 \mathrm{ml}$ of water. Precipitate was filtered out, washed by water, dried at $80-85^{\circ} \mathrm{C}$ and finally crystallized from propanol.

Method B. To the mixture of $3.42 \mathrm{~g}(0,01$ mole $)$ of xanthinyl-7-acetic acid 2,80 $\mathrm{ml}$ of propanol and $6 \mathrm{ml}$ of concentrated sulfuric acid 1.4-dioxane was added for full 
dissolution of acid 2. Solution, that was formed, was refluxed for $5 \mathrm{~h}$, cooled and diluted by $300 \mathrm{ml}$ of water. Precipitate was filtered out, washed by water, dried at $80-85^{\circ} \mathrm{C}$ and finally crystallized from propanol.

Yield $71 \%$. M.p. $165-169^{\circ}$ C. $\mathrm{C}_{20} \mathrm{H}_{24} \mathrm{~N}_{4} \mathrm{O}_{4}$. Found, \%: C, 62.09; H, 6.26; N, 14.45. Calculated, \%: C, 62.49; H, 6.29; N, 14.57. ${ }^{1} \mathrm{H}$ NMR-spectrum $\left(\delta\right.$-scale, ppm., solvent DMSO- $\left.d_{6}\right)$ : $11.02\left(1 \mathrm{H}, \mathrm{s}, \mathrm{N}^{1} \mathrm{H}\right), 7.36-7.11\left(5 \mathrm{H}, \mathrm{m}, \mathrm{CH}_{\text {аром }}\right), 5.14(2 \mathrm{H}, \mathrm{s}$, $\left.\mathrm{N}^{7}-\mathrm{CH}_{2}\right), 5.02\left(2 \mathrm{H}, \mathrm{s}, \mathrm{N}^{3}-\mathrm{CH}_{2}\right), 4.01\left(2 \mathrm{H}, \mathrm{t}, \mathrm{O}-\mathrm{CH}_{2}\right), 2.54(2 \mathrm{H}$, t, $\left.\mathrm{C}^{8}-\mathrm{CH}_{2}\right), 1.67\left(2 \mathrm{H}, \mathrm{m}, \mathrm{O}-\mathrm{C}-\mathrm{CH}_{2}\right), 1.53\left(2 \mathrm{H}, \mathrm{m}, \mathrm{C}^{8}-\mathrm{C}-\mathrm{CH}_{2}\right)$, $0.89\left(3 \mathrm{H}, \mathrm{t}, \mathrm{CH}_{3}\right), 0.67\left(3 \mathrm{H}, \mathrm{t}, \mathrm{O}-\mathrm{C}-\mathrm{C}-\mathrm{CH}_{3}\right)$.

Amide of 3-benzyl-8-propylxanthinyl-7-acetic acid was obtained by method A. $1.02 \mathrm{~g}$ ( 0.011 mole) of chloroacetoamide was used as reagent for alkylation.

Yield 77 \%. M.p. $289-292{ }^{\circ}$ C. $\mathrm{C}_{17} \mathrm{H}_{19} \mathrm{~N}_{5} \mathrm{O}_{3}$. Found, \%: C, 59.94; H, 5.59; N, 20.57. Calculated, \%: C, 59.81; H, 5.61; N, 20.52. ${ }^{1} \mathrm{H}$ NMR-spectrum ( $\delta$-scale, ppm., solvent DMSO- $\left.d_{6}\right)$ : $11.11\left(1 \mathrm{H}, \mathrm{s}, \mathrm{N}^{1} \mathrm{H}\right), 7.63(1 \mathrm{H}, \mathrm{s}, \mathrm{NH}), 7.37-7.18(5 \mathrm{H}, \mathrm{m}$, $\left.\mathrm{CH}_{\text {apos }}\right), 7.11(1 \mathrm{H}, \mathrm{s}, \mathrm{NH}), 5.02\left(2 \mathrm{H}, \mathrm{s}, \mathrm{N}^{3}-\mathrm{CH}_{2}\right), 4.82(2 \mathrm{H}$, $\left.\mathrm{s}, \mathrm{N}^{7}-\mathrm{CH}_{2}\right), 2.53\left(2 \mathrm{H}, \mathrm{t}, \mathrm{C}^{8}-\mathrm{CH}_{2}\right), 1.62\left(2 \mathrm{H}, \mathrm{m}, \mathrm{C}^{8}-\mathrm{C}-\mathrm{CH}_{2}\right)$, $0.87\left(3 \mathrm{H}, \mathrm{t}, \mathrm{CH}_{3}\right)$.

Ammonium salts of 3-benzyl-8-propylxanthinyl-7-acetic acid (5-15). Method A. To $0.5 \mathrm{~g}(0.0015$ mole) of acid $210 \mathrm{ml}$ of water and 0.0015 mole of appropriate amine were added. Mixture was heated up to full dissolution of acid. Solution was filtered, filtrate was cooled and acetone was added. Precipitate was filtered out and washed by acetone, diethyl ether and dried at $80-85^{\circ} \mathrm{C}$.

Method B. Mixture of $1.71 \mathrm{~g}(0,005$ mole $)$ acid 2, 0.005 mole of appropriative amine, $5 \mathrm{ml}$ of water and $20 \mathrm{ml}$ of propanol was heated up to dissolution and filtered. Filtrate was cooled up to $0{ }^{\circ} \mathrm{C}$ and left for $24 \mathrm{~h}$. Precipitate was filtered out and washed by acetone, diethyl ether and dried at $80-85^{\circ} \mathrm{C}$.

\section{Results and their discussion}

As initial compound for synthesis of 3-benzyl-8-propylxanthinyl-7-acetic acid 2 we used 3-benzyl-8-propylxanthine $\mathbf{1}$, which had been obtained by the method described by us earlier [10].

3-Benzyl-8-propylxanthinyl-7-acetic acid, its amide and propyl ester were synthesized using xanthine alkylation methodic [11]. Reaction was carried out in DMF in the presence of calculated amount of $\mathrm{NaHCO}_{3}$ and addition chloroacetic acid, chloroacetamide or propyl chloroacetate as reagents (Fig. 1).

It should be noted, that xanthinyl-7-acetic acid $\mathbf{2}$ was obtained with higher yield as result of hydrolysis of ester $\mathbf{3}$ and amide 4. Ester 3 was also synthesized by interaction of acid $\mathbf{2}$ and propanol in the presence of dioxane and catalytic amount of concentrated sulfuric acid. Samples of compounds, that were obtained by different methods, didn't show depression of melting points and their ${ }^{1} \mathrm{H}$ NMR-spectra were identical.

3-Benzyl-8-propylxanthinyl-7-acetic acid $\mathbf{2}$ is pale yellow crystal compound, that is soluble in propanol, dioxane, DMF, DMSO, and aqueous solution of $\mathrm{NaOH}$. Acid 2 also interact with $\mathrm{NaHCO}_{3}$ with $\mathrm{CO}_{2}$ gassing that proved presence of carboxyl group in the structure of compound 2 .<smiles>CCCc1nc2c([nH]1)c(=O)[nH]c(=O)n2Cc1ccccc1</smiles>
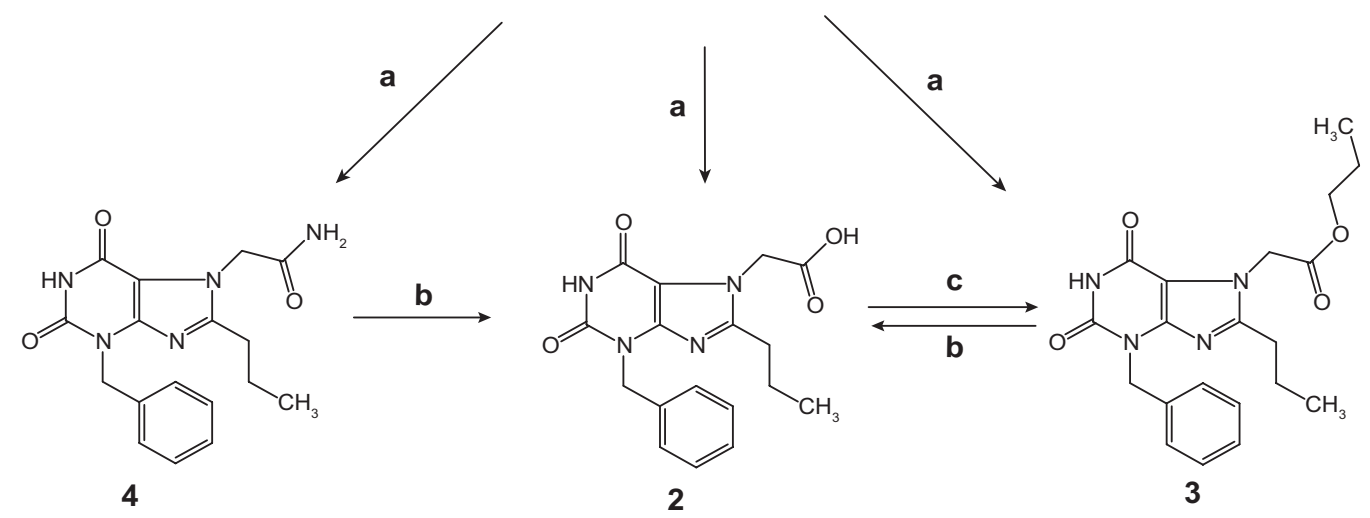

a) chloroacetic acid, chloroacetamide or propyl chloroacetate, $\mathrm{DMF}, \mathrm{NaHCO}_{3}$, reflux.

b) $\mathrm{NaOH}, \mathrm{H}_{2} \mathrm{O}$, reflux, c) propanol, dioxane, $\mathrm{H}_{2} \mathrm{SO}_{4}$, reflux.

Fig. 1. Scheme of 3-benzyl-8-propylxanthinyl-7-acetic acid, its ester and amide synthesis. 
In ${ }^{1} \mathrm{H}$ NMR-spectrum of acid 2 (Table 1) we registered signal of carboxyl group proton as low intensive singlet at weak filed at 12,61 ppm, and intensive singlet of $\mathrm{CH}_{2}$-group at 4,97 ppm, that confirmed acetate residue presence. Other signals corresponded to the protons of NH-group of xanthine heterocycle and methyl, methylene and aromatic groups of side-chain residues.

Propyl 3-benzyl-8-propylxanthinyl-7-acetate $\mathbf{3}$ is a white amorphous compound, soluble in ethanol, propanol, dioxane, DMF, DMSO and insoluble in water.

In ${ }^{1} \mathrm{H}$ NMR-spectrum of ester 3 were absent signals of NHgroup of imidazole fragment or hydroxyl group of carboxyl, that were present in spectra of initial 8-propylxanthine 1 [10] or acid 2. Instead of this we registered: intensive singlets of two methylene groups protons $(2 \mathrm{H})$, that associated with Nitrogen atoms at position 3 and 7 of xanthine molecule at $5.02 \mathrm{ppm}$ and $5.14 \mathrm{ppm}$; protons of methyl and methylene groups of ester fragment resonated as two triplets at $4.01 \mathrm{ppm}$ $(2 \mathrm{H})$ and at $0.67 \mathrm{ppm}(6 \mathrm{H})$ and one multiplet at $1.67 \mathrm{ppm}$ $(2 \mathrm{H})$ respectively.

In ${ }^{1} \mathrm{H}$ NMR-spectrum of amide 4 the presence of acetamide residue was confirmed by the next signals: singlets of amide protons at $7.63 \mathrm{ppm}(1 \mathrm{H})$ and $7.11 \mathrm{ppm}(1 \mathrm{H})$ and intensive singlet of methylene group at $4.82 \mathrm{ppm}$.

The next stage of our synthetic research was obtaining water-soluble salts of 3-benzyl-8-propylxanthinyl-7-acetic acid 5-15 by heating of acid 2 with different primary, secondary aliphatic amines in water or aqueous propanol (Fig. 2).

Synthesized ammonium salts were white or pale yellow crystal compounds, soluble in water and insoluble in diethyl ester and acetone.

Physical-chemical properties of synthesized compounds 5-15 are represented in the Table 1.

Table 1. Physical-chemical properties of synthesized compounds 5-15

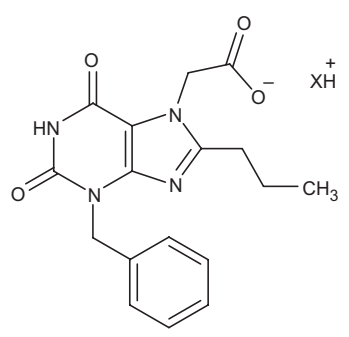

\begin{tabular}{|c|c|c|c|c|c|c|c|c|c|c|}
\hline \multirow{2}{*}{ غَّ } & \multirow{2}{*}{$x$} & \multirow{2}{*}{ m.p. } & \multicolumn{3}{|c|}{ Found, \% } & \multirow{2}{*}{ Formula } & \multicolumn{3}{|c|}{ Calculated, \% } & \multirow{2}{*}{ Yield, \% } \\
\hline & & & C & $\mathrm{H}$ & $\mathrm{N}$ & & C & $\mathrm{H}$ & $N$ & \\
\hline 5 & $\mathrm{NH}_{3}$ & $165-7$ & 56.63 & 5.85 & 19.43 & $\mathrm{C}_{17} \mathrm{H}_{21} \mathrm{~N}_{5} \mathrm{O}_{4}$ & 56.82 & 5.89 & 19.49 & 87 \\
\hline 6 & $\mathrm{NH}_{2} \mathrm{C}_{2} \mathrm{H}_{5}$ & $224-6$ & 58.63 & 6.47 & 18.04 & $\mathrm{C}_{19} \mathrm{H}_{25} \mathrm{~N}_{5} \mathrm{O}_{4}$ & 58.90 & 6.50 & 18.08 & 82 \\
\hline 7 & & $224-7$ & 59.77 & 6.80 & 17.46 & $\mathrm{C}_{20} \mathrm{H}_{27} \mathrm{~N}_{5} \mathrm{O}_{4}$ & 59.84 & 6.78 & 17.44 & 89 \\
\hline 8 & $\mathrm{NH}_{2} \mathrm{C}_{4} \mathrm{H}_{9}-\mathrm{n}$ & $185-9$ & 60.81 & 7.01 & 16.82 & $\mathrm{C}_{21} \mathrm{H}_{29} \mathrm{~N}_{5} \mathrm{O}_{4}$ & 60.71 & 7.04 & 16.86 & 74 \\
\hline 9 & $\mathrm{NH}_{2} \mathrm{CH}_{2} \mathrm{CH}_{2} \mathrm{OH}$ & $220-4$ & 56.38 & 5.93 & 17.89 & $\mathrm{C}_{19} \mathrm{H}_{25} \mathrm{~N}_{5} \mathrm{O}_{5}$ & 56.57 & 6.25 & 17.36 & 83 \\
\hline 10 & & $186-9$ & 58.52 & 6.33 & 16.27 & $\mathrm{C}_{21} \mathrm{H}_{27} \mathrm{~N}_{5} \mathrm{O}_{5}$ & 58.73 & 6.34 & 16.31 & 83 \\
\hline 11 & $\mathrm{H}_{2} \mathrm{~N}$ & $154-6$ & 56.88 & 6.33 & 18.84 & $\mathrm{C}_{21} \mathrm{H}_{28} \mathrm{~N}_{6} \mathrm{O}_{5}$ & 56.75 & 6.35 & 18.91 & 77 \\
\hline 12 & $\mathrm{H}_{2} \mathrm{~N}^{\prime}$ & $167-70$ & 63.96 & 6.03 & 15.49 & $\mathrm{C}_{24} \mathrm{H}_{27} \mathrm{~N}_{5} \mathrm{O}_{4}$ & 64.13 & 6.05 & 15.58 & 79 \\
\hline 13 & $\mathrm{H}_{2} \mathrm{~N}^{\prime}$ & $188-94$ & 61.53 & 5.58 & 14.93 & $\mathrm{C}_{24} \mathrm{H}_{26} \mathrm{FN}_{5} \mathrm{O}_{4}$ & 61.66 & 5.61 & 14.98 & 69 \\
\hline 14 & & $165-7$ & 64.59 & 6.32 & 15.03 & $\mathrm{C}_{25} \mathrm{H}_{29} \mathrm{~N}_{5} \mathrm{O}_{4}$ & 64.78 & 6.31 & 15.11 & 68 \\
\hline 15 & $\mathrm{H}_{2} \mathrm{~N}$ & $167-70$ & 59.51 & 5.61 & 15.73 & $\mathrm{C}_{22} \mathrm{H}_{25} \mathrm{~N}_{5} \mathrm{O}_{5}$ & 60.13 & 5.73 & 15.94 & 78 \\
\hline
\end{tabular}


<smiles>CCCc1nc2c(c(=O)[nH]c(=O)n2Cc2ccccc2)n1CC(=O)O</smiles><smiles>Oc1ccccc1</smiles><smiles>[Z][O+]C(=O)Cn1c(CCC)nc2c1c(=O)[nH]c(=O)n2Cc1ccccc1</smiles>

$X=$ ammonium, ethylamine, isopropylamine, butylamine, monoethanolamine, morpholine, $\mathrm{N}$-aminomorpholine, benzylamine, 4-fluorobenzylamine, phenylethylamine, furfurylamine

Fig 2. Scheme of water-soluble 3-benzyl-8-propylxanthinyl-7-acetates synthesis.

\section{Conclusions}

1. We have developed the method of synthesis of 3-benzyl-8-propylxanthinyl-7-acetic acid, its propyl ester and amide by alkylation of 3-benzyl-8-propylxanthine.

2. We have found that obtaining of 3-benzyl-8-propylxanthinyl-7-acetic acid by hydrolysis of its ester is produced with the higher yield.

3. A number of water-soluble salts of 3-benzyl-8-propylxanthinyl-7-acetic acid have been obtained by reaction of acid with different primary and secondary amines.

4. The structures of all obtained compounds have been proved by the elemental analysis and 1H NMR-spectroscopy.

\section{References}

[1] Lieberman, M., Marks, A., \& Smith, C. (2007) Marks' Essential Medical Biochemistry. Lippincott Williams \& Wilkins.

[2] Joule, J. A., \& Mills, K. (2012) Heterocycles in Nature. Heterocyclic Chemistry at a Glance (2nd ed). (P. 158-166). Chichester: John Wiley \& Sons, Ltd.

[3] Joule, J. A., \& Mills K. (2012) Heterocycles in Medicine. Heterocyclic Chemistry at a Glance (2nd ed). (P. 167-179). Chichester: John Wiley \& Sons, Ltd.

[4] Müller, C. E., Sandoval-Ramírez, J., Schobert, U., Geis, U., Frobenius, W., \& Klotz, K. N. (1998) 8-(Sulfostyryl) xanthines: water-soluble $\mathrm{A}_{2 \mathrm{~A}}$-selective adenosine receptor antagonists. Bioorganic \& Medicinal Chemistry, 6, 707-719. doi: 10.1016/S0968-0896(98)00025-X.

[5] Mohamed, T., Osman, W., Tin, G., \& Rao, P. N. (2013) Selective inhibition of human acetylcholinesterase by xanthine derivatives: In vitro inhibition and molecular modeling investigations. Bioorganic \& Medicinal Chemistry Letters, 23, 4336-4341. doi: 10.1016/j.bmcl.2013.05.092.

[6] Mak, G., \& Hanania, N. A. (2012) New bronchodilators. Curr. Op. Pharmacol, 12, 238-245.

[7] Song, B., Xiao, T., Qi, X., Li, L. N., Qin, K., Nian, S., et al. (2012) Design and synthesis of 8-substituted benzamido-phenylxanthine derivatives as MAO-B inhibitors. Bio- organic \& Medicinal Chemistry Letters, 22, 1739-1742. doi: 10.1016/j.bmcl.2011.12.094.

[8] Yadav, R., Bansal, R., Rojilla, S., Kachler, S., \& Klotz, K. N. (2016) Synthesis and pharmacological characterization of novel xanthine carboxylate amides as $\mathrm{A}_{2 \mathrm{~A}}$ adenosine receptor ligands exhibiting bronchospasmolytic activity. Bioorganic Chemistry, 65, 26-37. doi: 10.1016/j.bioorg.2016.01.003.

[9] Lupascu, F. G., Dash, M., Samal, S. K., Dubruel, P., Lupusoru, C. E., Lupusoru, R. V., et al. (2015) Development, optimization and biological evaluation of chitosan scaffold formulations of new xanthine derivatives for treatment of type-2 diabetes mellitus. European Journal of Pharmaceutical Sciences, 77, 122-134. doi.org/10.1016/j.ejps.2015.06.008.

[10] Mikhal'chenko, Ye. K., Aleksandrova, K. V., \& Levich, S. V. (2016) Syntez i fizyko-khimichni vlastyvosti 3-benzyl-8-propilksantynu ta yoho vodorozchynnykh solei [Synthesis and physical-chemical properties of 3-benzyl-8-propylxanthine and its water-soluble salts]. Current issues in pharmacy and medicine: science and practice, 1, 26-30. doi: 10.14739/24092932.2016.1.62005. [in Ukrainian].

[11] Aleksandrova, E. V., Levich, S. V., Romanenko, N. I., Shkoda, A. S., \& Mikhalchenko, E. K. (2014) Synthesis, transformations, and physicochemical properties of 3-(4'-methylphenyl)-8-methylxanthine derivatives. Chem. Nat. Comp., 49(6), 1105-1109. doi: 10.1007/s10600-014-0830-2.

\section{Information about authors:}

Mikhalchenko E. K., Senior Assistant, the Department of Biological Chemistry, Zaporizhzhia State Medical University, Ukraine. Aleksandrova K. V., Dr.hab., Professor, Head of the Department of Biochemistry, Zaporizhzhia State Medical University, Ukraine. Levich S. V., Ph.D., Teaching Assistant, the Department of Biochemistry, Zaporizhzhia State Medical University, Ukraine. Sinchenko D. M., Ph.D., Teaching Assistant, the Department of Biological Chemistry, Zaporizhzhia State Medical University, Ukraine.

\section{Відомості про авторів:}

Михальченко Є. К., старший лаборант каф. біологічної хімії, Запорізький державний медичний університет, Україна. Александрова К. В., д-р хім. наук, професор, зав. каф. біологічної хімії, Запорізький державний медичний університет, Україна.

Левіч С. В., канд. фарм. наук, асистент каф. біологічної хімії, Запорізький державний медичний університет, Україна. Сінченко Д. М., канд. фарм. наук, асистент каф. біологічної хімії, Запорізький державний медичний університет, Україна. 


\section{Сведения об авторах:}

Михальченко Е. К., старший лаборант каф. биологической химии, Запорожский государственный медицинский университет, Украина.

Александрова Е. В., д-р хим. наук, профессор, зав. каф. биологической химии, Запорожский государственный медицинский университет, Украина.

Левич С. В., канд. фарм. наук, ассистент каф. биологической химии, Запорожский государственный медицинский университет, Украина.

Синченко Д. Н., канд. фарм. наук, ассистент каф. биологической химии, Запорожский государственный медицинский университет, Украина.

E-mail:rshlevas@gmail.com

Конфлікт інтересів: відсутній.

Conflicts of Interest: authors have no conflict of interest to declare.

Надійшло до редакції / Received: 22.11.2016

Після доопрацювання / Revised: 01.12.2016

Прийнято до друку / Accepted: 10.01.2017 